\title{
POTENSI IKAN GABUS (OPHIOCEPHALUS STRIATUS) DALAM MEMPERCEPAT PENYEMBUHAN LUKA
}

\author{
Robert Tungadi*1 \\ 1Jurusan Farmasi, Fakultas Olahraga dan Keseehatan, Universitas Negeri Gorontalo \\ Jl.Jenderal Sudirman No.06, Kota Gorontalo 96128, Gorontalo, Indonesia \\ *Email: robert.tungadi@ung.ac.id \\ (Diterima 13-02-2020 / Dipublikasi 13-02-2020)
}

\begin{abstract}
ABSTRAK
Ikan gabus (Ophiocephalus striatus) merupakan jenis ikan yang hidup di air tawar dan sudah banyak dikenal oleh masyarakat. Khasiat dan kegunaan ikan gabus telah terbukti secara ilmiah dapat meningkatkan kadar albumin dan daya tahan tubuh serta mempercepat proses penyembuhan luka pasca-operasi. Adapun kandungan gizi dari ikan gabus terdiri dari protein albumin, asam-asam amino, asam lemak tak jenuh dan mineral. Senyawa bioaktif yang berperan dalam mempercepat proses penyembuhan luka adalah albumin, glisin, dan seng (Zn). Penyembuhan luka sangat bergantung pada proses biokimia yang terjadi pada kulit yang melibatkan faktor intrinsik dan ekstrinsik. Proses penyembuhan ini akan dipercepat dengan bantuan dari ekstrak kering ikan gabus yang dirancang dalam bentuk topikal seperti krim atau gel. Baik albumin, glisin dan $\mathrm{Zn}$ ini penting untuk penyembuhan luka karena protein ini mampu mengikat $\mathrm{Zn}$ dan membawanya dalam plasma darah. Kekurangan $\mathrm{Zn}$ mengurangi proses penyembuhan luka. Karena nutrisi ini, dan vitamin lainnya, hadir dalam ekstrak ikan gabus sehingga dapat memicu pembentukan Sel Progenitor Endotel (EPC) dan mempercepat penyembuhan luka. Kehadiran Zn dalam ekstrak ikan gabus kemungkinan menjadi faktor kunci yang berperan dalam penyembuhan luka dan juga meningkatkan nafsu makan anak-anak. $\mathrm{Zn}$ adalah mineral penting dalam struktur dan fungsi membran sel. Suplementasi $\mathrm{Zn}$ dapat membatasi kerusakan membran yang disebabkan oleh radikal bebas selama peradangan. Selanjutnya, Zn juga terlibat dalam sistem kekebalan tubuh, mulai dari sistem pertahanan oleh kulit hingga regulasi gen dalam limfosit.
\end{abstract}

Kata kunci: Akan gabus; albumin; Glisin; Luka; Zenk.

\section{ABSTRACT}

Cork fish (Ophiocephalus striatus) is a type of fish that lives in freshwater and is widely known by the public. The properties and uses of cork fish have been scientifically proven to increase albumin levels and the immune system as well as speed up the process of post-operative wound healing. The nutritional content of cork fish consists of albumin protein, amino acids, unsaturated fatty acids, and minerals. Bioactive compounds that play a role in accelerating the wound healing process are albumin, glycine, and zinc (Zn). Wound healing is very dependent on the biochemical processes that occur on the skin involving intrinsic and extrinsic factors. This healing process will be accelerated with the help of dried cork fish extract which is designed in a topical form such as cream or gel. Both albumin, glycine, and $\mathrm{Zn}$ are important for wound healing because this protein can bind $\mathrm{Zn}$ and carry it in blood plasma. $\mathrm{Zn}$ deficiency reduces the process of wound healing. Because this nutrient, and other vitamins, are present in cork fish extract so that it can trigger the formation of Endothelial Progenitor Cells (EPC) and accelerate wound healing. The presence of $\mathrm{Zn}$ in cork fish extract is likely to be a key factor that plays a role in wound healing and also increases the appetite of children. $\mathrm{Zn}$ is an important mineral in the structure and function of cell membranes. $\mathrm{Zn}$ supplementation can limit membrane damage caused by free radicals during inflammation. Furthermore, $\mathrm{Zn}$ is also involved in the immune system, from the defense system by the skin to the regulation of genes in lymphocytes.

Key words: Will cork; albumin; Glycine; zenk; The wound 
PENDAHULUAN

Indonesia merupakan Negara kepulauan yang kaya bahan alam dari tumbuhan laut maupun hewan laut. Salah satunya adalah Provinsi Gorontalo yang mempunyai Danau Limboto penghasil ikan gabus. Ikan gabus (Ophiocephalus striatus) merupakan jenis ikan yang hidup di air tawar dan sudah banyak dikenal oleh masyarakat. Ikan gabus (Ophiocephalus striatus) merupakan salah satu ikan air tawar maupun air payau yang juga termasuk dalam jenis ikan pancingan yang banyak ditemui di sungai, rawa, danau dan saluran-saluran air hingga ke sawah-sawah (Sulthoniyah, et al, 2013). Khasiat dan kegunaan ikan gabus telah terbukti secara ilmiah dapat meningkatkan kadar albumin dan daya tahan tubuh serta mempercepat proses penyembuhan luka pasca-operasi (Ulandari, et al, 2010).

Pada umumnya, pengobatan tradisional yang sudah dilakukan masyarakat Indonesia khususnya masyarakat Gorontalo dengan cara merebus ikan gabus untuk diperoleh ekstraknya kemudian diminumkan kepada pasien yang kekurangan gizi atau untuk luka pascaoperasi sehabis melahirkan. Pada dasarnya pemberian ekstrak air ikan gabus pada pasien kurang disenangi baunya sehingga banyak pasien yang tidak menyukainya. Oleh karena itu, para peneliti sebelumnya sudah membuat dalam bentuk sediaan kapsul yang diminumkan kepada pasien luka pasca bedah dan efek topikal terhadap kulit luka telah dilakukan secara preklinik terhadap hewan coba yang hasilnya menunjukkan konsentrasi krim 2\% ekstrak kering ikan gabus memberikan proses penyembuhan luka yang cepat dalam waktu 3 hari dibandingkan dengan konsentrasi krim lainnya (Tungadi, 2008).

Pada masa krisis saat ini, serum albumin impor yang digunakan sering membebani biaya pasien. Untuk satu kali pembedahan, penggunaan serum ini bisa mencapai tiga kali $100 \mathrm{ml}$. Dari hasil penelitian Suprayitno (2003), ternyata ikan gabus yang ada di Indonesia mempunyai kandungan albumin dan asam-asam amino yang tinggi dibandingkan dengan ikan air tawar lainnya seperti ikan lele, nila, mas, gurami dan sebagainya. Hasil penelitian Taslim, dkk, (2005) menunjukkan bahwa pemberian ekstrak air ikan gabus sebanyak $100 \mathrm{ml}$ setiap hari selama 3 hari telah dapat meningkatkan kadar albumin dan total protein pasien. Rata-rata besar peningkatan kadar albumin sebesar 0,7 $\mathrm{g} / \mathrm{dl} / \mathrm{hari}$ dibandingkan dengan kelompok kontrol. Hasil penelitian Hidayanti (2006) menunjukkan bahwa pemberian albumin untuk penyembuhan luka dalam bentuk kapsul ikan gabus setiap hari selama 5 hari pada pasien pasca bedah yang hipoalbumin di Rumah Sakit Wahidin 


$\begin{array}{ll}\text { Sudirohusodo, Makassar telah dapat } & \text { Filum : Chordata } \\ \text { meningkatkan kadar albumin rata-rata } & \text { Kelas : Actinopterygii } \\ \text { sebesar 0,74 g/dl/hari diikuti oleh peningkatan } & \text { Frdo : Perceformes } \\ \text { status gizi dibandingkan dengan kelompok } & \text { Genus : Ophiocephalus } \\ & \text { Spesies: Ophiocephalus striatus }\end{array}$
kontrol.

Keefektifan Ikan Gabus sebagai bahan penyembuh luka dipengaruhi oleh tingginya kandungan asam amino tertentu, seperti glisin dan asam lemak tak jenuh seperti omega-3, dipercaya terlibat dalam promosi penyembuhan luka melalui inisisasi dari rangkaian reaksi yang melibatkan remodelingcollagen, re-epitelisasi luka dan induksi kontraksi luka. Disamping itu, ekstrak Ikan Gabus juga memiliki kemampuan untuk menyebabkan proliferasi terhadap sel mesenchymal dan mempertahankan viabilitas sel untuk digunakan sebagai bahan biokimia dan promoter penyembuhan yang tidak terbatas pada luka kulit.

Oleh karena itu, dalam review ini pengarang akan membahas tentang potensi ikan gabus dalam mempercepat proses penyembuhan luka ditinjau dari senyawa biokimia yang terkandung dalam ikan gabus dan bentuk bentuk sediaan farmasi yang berasal dari ikan gabus.

\section{IKAN GABUS}

\section{Klasifikasi Ikan Gabus}

Klasifikasi ilmiah ikan gabus, menurut Lawang, T.A (2013) adalah sebagai berikut:

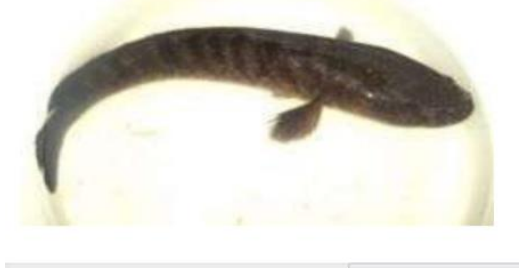

Gambar 1. Ikan gabus

\section{Kandungan Ikan Gabus}

Ikan gabus diketahui mengandung albumin dan jenis protein lainnya yang sangat penting bagi kesehatan. Penggunaan ikan gabus untuk pengobatan telah dilakukan di beberapa daerah. Di Sulawesi Selatan, ikan gabus dikonsumsi oleh perempuan yang baru melahirkan. Dengan mengonsumsi ikan gabus, diharapkan perempuan yang melahirkan cepat sembuh dan menghasilkan ASI (air susu ibu) yang banyak untuk kebutuhan bayinya. Di daerah Tanah Toraja dan Enrekang, ikan gabus diberikan sejak dulu kepada anak-anak karena dipercaya dapat meningkatkan kekebalan tubuh anakanak (Ghufran, 2010). Berdasarkan tabel kandungan ikan gabus (Suprapti, 2008), jumlah gizi ikan gabus per 100 gram bahan dapat dilihat pada Tabel 1. 
Tabel. 1 Kandungan gizi ikan gabus berdasarkan per 100 gram bahan

\begin{tabular}{llc}
\hline No. & Unsur Gizi & Jumlah / satuan \\
\hline 1. & Energi & $116 \mathrm{kal}$ \\
2. & Air & $69,6 \mathrm{~g}$ \\
3. & Protein & $25,2 \mathrm{~g}$ \\
4. & Lemak & $1,7 \mathrm{~g}$ \\
5. & Karbohidrat & $0 \mathrm{~g}$ \\
6. & Lemak & $3,6 \mathrm{~g}$ \\
7. & Kalsium & $62 \mathrm{mg}$ \\
8. & Fosfor & $176 \mathrm{mg}$ \\
9. & Besi & $0,9 \mathrm{mg}$ \\
10. & Vitamin A & $45 \mathrm{mcg}$ \\
11. & Vitamin B & $0,04 \mathrm{mcg}$ \\
12. & Vitamin C & $0 \mathrm{mg}$ \\
\hline \multicolumn{2}{l}{ Sumber : Daftar Analisis } & Bahan Makanan, Fakultas \\
\multicolumn{2}{l}{ Kedokteran Ul Jakarta }
\end{tabular}

Ikan gabus memiliki kandungan protein yang tinggi yang diperlukan dalam masa pertumbuhan, kehamilan, atau menyusui. Angka Kecukupan Protein (AKP) orang dewasa FAO/WHO/UNU (1985) adalah 0,75 $\mathrm{g} / \mathrm{kg}$ berat badan, kebutuhan protein manusia dewasa per hari tidak boleh kurang dari 0,6$0,7 \mathrm{~g}$ protein per berat kilogram berat badan. Khususnya bagi mereka yang tidak memiliki kelainan metabolisme. Pada pria dewasa dengan bobot $65 \mathrm{~kg}$ dibutuhkan sedikitnya 37 $62 \mathrm{~g}$ protein per hari. Pada wanita dewasa dengan bobot $55 \mathrm{~kg}$ dibutuhkan sedikitnya 29 $48 \mathrm{~g}$ protein per hari. Menurut Kepmenkes (2005) kebutuhan protein ikan gabus dalam masa pertumbuhan balita perhari dapat dilihat pada tabel 2.

Para peneliti di Asia Tenggara, khususnya Malaysia dan Indonesia, telah membuktikan bahwa ikan gabus merupakan salah satu ikan penting bagi kesehatan umat manusia. Konsentrat protein serbuk ikan gabus telah terbukti mampu mempercepat penyembuhan penyakit infeksi dan meningkatkan daya tahan tubuh karena kandungan protein albuminnya (Tawali, et al. 2012).

Tabel 2. Jumlah Konsumsi Ikan Gabus per Orang per Hari dalam Memenuhi Kebutuhan Protein Tubuh

\begin{tabular}{llll}
\hline \multicolumn{5}{l}{ No.Kelompok Umur Protein (G) lkan } & Gabus (gram) \\
\hline 1. & $0-6$ bulan & 10 & 39.68 \\
2. & $7-11$ bulan & 16 & 63,49 \\
3. & $1-3$ bulan & 25 & 99,20 \\
4. & $4-6$ tahun & 39 & 154,76
\end{tabular}

Sumber : KEPMENKES 2005

Albumin merupakan fraksi utama protein plasma berbentuk elips dan mempunyai berat molekul dan $\mathrm{pH}$ isoelektrik bervariasi tergantung spesies. Berat molekul albumin plasma manusia 69.000 , albumin telur 44.000, dan di dalam daging mamalia adalah 63.000 (Montgomery, 1993). pH isoeletrik albumin bervariasi antara 4,6 (albumin telur) sampai 4,9 (albumin serum). Albumin manusia yang matur terdiri dari suatu rantai polipeptida. Albumin kaya akan asam amino lisin, arginin, asam glutamat, dan asam aspartat (Sunatrio, 2003).

Kandungan gizi yang terdapat dalam ikan gabus dapat dilihat pada tabel 3 dan 4 . 
Tabel 3. Kandungan gizi ikan gabus

\begin{tabular}{|c|c|}
\hline No. & Kandungan gizi Jumlah bahan \\
\hline 1. & Protein \\
\hline 2. & Albumin $30,2 \%$ \\
\hline 3. & Lemak \\
\hline 4. & Omega-3 2,03\% \\
\hline 5. & Omega-6 2,11\% \\
\hline 6. & Omega-9 $0,92 \%$ \\
\hline 7. & Vitamin A $1500 \mathrm{lU} / 100 \mathrm{~g}$ \\
\hline 8. & $0,9 \mathrm{mg} / 100 \mathrm{~g}$ \\
\hline 9. & $1,11 \mathrm{mg} / 100 \mathrm{~g}$ \\
\hline 10. & $0,70 \mathrm{mg} / 100 \mathrm{~g}$ \\
\hline 11. & $0,76 \mathrm{mg} / 100 \mathrm{~g}$ \\
\hline 12. & Vitamin $\mathrm{E} 9,11 \mathrm{mg} / 100 \mathrm{~g}$ \\
\hline 13. & $51,5 \mathrm{mg} / 100 \mathrm{~g}$ \\
\hline 14. & $186 \mathrm{mg} / 100 \mathrm{~g}$ \\
\hline 15. & $126 \mathrm{mg} / 100 \mathrm{~g}$ \\
\hline 16. & Magnesium (Mg) $39 \mathrm{mg} / 100 \mathrm{~g}$ \\
\hline 17. & $3,0 \mathrm{mg} / 100 \mathrm{~g}$ \\
\hline 18. & Anti bakteri lg+ \\
\hline 19. & Asam arakidonat $20,11 \mathrm{mg} / 100 \mathrm{~g}$ \\
\hline
\end{tabular}

Sumber: PT. Royal Medica Pharmaceuticals, Makassar

Tabel 4. Kandungan Asam Amino dalam Albumin Ikan Gabus

\begin{tabular}{|c|c|c|}
\hline No & Kandungan asam amino & Jumlah bahan \\
\hline 1. & Aspartat & $1,04 \mathrm{~g} / 100 \mathrm{~g}$ \\
\hline 2. & Glutamat & $15,0 \mathrm{~g} / 100 \mathrm{~g}$ \\
\hline 3. & Serin & $1,0 \mathrm{~g} / 100 \mathrm{~g}$ \\
\hline 4. & Glisin & $1,11 \mathrm{~g} / 100 \mathrm{~g}$ \\
\hline 5. & Alanin & $2,11 \mathrm{~g} / 100 \mathrm{~g}$ \\
\hline 6. & Leusin & $1,60 \mathrm{~g} / 100 \mathrm{~g}$ \\
\hline 7. & Isoleusin & $0 \mathrm{~g} / 100 \mathrm{~g}$ \\
\hline 8. & Valin & $2,11 \mathrm{~g} / 100 \mathrm{~g}$ \\
\hline 9. & Triptophan & $3,0 \mathrm{~g} / 100 \mathrm{~g}$ \\
\hline 10. & Hidroksi Prolin & $8,10 \mathrm{~g} / 100 \mathrm{~g}$ \\
\hline 11. & Prolin & $1,0 \mathrm{~g} / 100 \mathrm{~g}$ \\
\hline 12. & Phenilalanin & $0.81 \mathrm{~g} / 100 \mathrm{~g}$ \\
\hline 13. & Histidin & $1,0 \mathrm{~g} / 100 \mathrm{~g}$ \\
\hline 14. & Sistein & $1.07 \mathrm{~g} / 100 \mathrm{~g}$ \\
\hline 15. & Lysin & $1,46 \mathrm{~g} / 100 \mathrm{~g}$ \\
\hline 16. & Tirosin & $0,92 \mathrm{~g} / 100 \mathrm{~g}$ \\
\hline
\end{tabular}

\section{LUKA}

Pembedahan atau operasi adalah semua tindakan pengobatan yang menggunakan cara inpasif dengan membuka atau menampilkan bagian tubuh yang akan ditangani. Pembukaan bagian tubuh ini umumnya dengan membuat sayatan, setelah bagian yang akan ditangani ditampilkan, dilakukan perbaikan yang diakhiri dengan penutupan dan penjahitan luka (Jahoor, 1999).

Sebagai salah satu bentuk terapi, pembedahan tergolong unik. Penderita yang sudah dalam keadaan stress akibat penyakitnya, akan mendapat tambahan stress atau trauma serta kemungkinan terjadi sepsis sewaktu menjalani terapi pembedahan. Pengaruh buruk dari stress terhadap gizi akan berlipat ganda pula mengingat penyembuhan selalu berhubungan dengan status gizi. Perubahan metabolik, penilaian status gizi, kebutuhan gizi, dan dukungan gizi harus diperhatikan pada setiap pembedahan (Simajuntak, 1994).

Proses pembedahan sengaja dibuat luka sehingga terjadi stress yang menyebabkan perubahan metabolik akibat reaksi endokrin yang kompleks, sebagai akibat dari proses penyembuhan luka serta banyak faktor yang terkait. Penyembuhan luka dapat terganggu karena adanya faktor endogen dan eksogen. Jika terjadi penyembuhan luka berarti terjadi komplikasi atau gangguan dalam hasil pembedahan, dengan demikian keadaan malnutrisi akan mempengaruhi proses penyembuhan luka (Daldiono, 1998). 
Luka pada tubuh dapat menimbulkan proses katabolik secara menyeluruh yang berhubungan dengan kehilangan berat badan, anoreksia, rasa lelah dengan penurunan aktivitas serta banyak keluhan secara klinik yang dikaitkan dengan respon metabolik (Wilmore, 2001)

Respon metabolik dari luka yang disebabkan oleh prosedur pembedahan menyebabkan kehilangan nitrogen dari tubuh. Negative Nitrogen Balance disebabkan oleh peningkatan ekskresi urea dan produk nitrogen lain melalui urin. Demikian juga dengan banyaknya luka yang terbuka (seperti luka bakar) dimana terjadi kehilangan protein dalam jaringan (Wilmore, 2001).

Gangguan gizi pada pasien pasca bedah disebabkan oleh rendahnya asupan zat gizi sehingga simpanan zat gizi dalam tubuh digunakan untuk mencukupi kebutuhan fisiologis. Bila keadaan ini tidak diperbaiki dan terus menerus berlanjut akan mengakibatkan perubahan biokimia tubuh yang ditandai dengan rendahnya beberapa kadar zat gizi dalam tubuh seperti $\mathrm{Hb}$, albumin serum, vitamin A dan lain-lain. Apabila keadaan ini terus berlangsung, lama kelamaan simpanan zat gizi akan habis dan terjadilah penurunan jaringan yang ditandai dengan penurunan berat badan. Hal ini memudahkan terkena infeksi atau infeksi menjadi lebih parah (Supariasa, 2002; Almatsier, 2001).
Trauma akan menghasilkan respon neuroendokrin yang mengakibatkan perubahan-perubahan kadar hormon yang sangat berubah dari yang diamati pada starvasi yang berkepanjangan. Kortisol, glukagon, katekolamin, epinefrin dan norepinefrin meningkat sebanding dengan derajat trauma. Hormon ini menyebabkan proteolisis otot (kortisol), glikogenesi dan peningkatan glukoneogenesis serta oksidasi lemak (Hill, 2000).

Perubahan dasar yang terlihat pada stress fisiologik ini juga dijumpai pada kondisi bedah dimana pada trauma dan sepsis kebutuhan glukosa yang meningkat dipenuhi dengan asam-asam amino yang dihasilkan dari pemecahan protein otot. Glukosa yang meningkat ini dihasilkan untuk memenuhi kebutuhan energi dari otak, luka dan tempattempat yang terinfeksi atau cedera (Hill, 2000).

Luka adalah hilang atau rusaknya sebagian jaringan tubuh. Keadaan ini dapat disebabkan oleh trauma benda tajam atau tumpul, perubahan suhu, zat kimia, ledakan, sengatan listrik, atau gigitan hewan (Sjamsuhidajat, 1997).

Proses yang kemudian terjadi pada jaringan yang rusak ini ialah penyembuhan luka yang dapat dibagi dalam tiga fase yaitu fase inflamasi, poliferasi, dan penyudahan 
yang merupakan perupaan kembali (remodelling) jaringan.

1. Fase inflamasi

Fase inflamasi berlangsung sejak terjadinya luka sampai kira-kira hari kelima. Pembuluh darah yang terputus pada luka akan menyebabkan perdarahan dan tubuh akan berusaha menghentikannya dengan vasokontriksi, pengerutan ujung pembuluh yang putus (retraksi), dan reaksi hemostatis. Hemostatis terjadi karena trombosit yang keluar dari pembuluh darah saling melengket, dan bersama dengan jala fibrin yang terbentuk membekukan darah yang keluar dari pembuluh darah. Sementara itu terjadi reaksi inflamasi.

Sel mast dalam jaringan ikat menghasilkan serotonin dan histamin yang meningkatkan permeabilitas kapiler sehingga terjadi eksudasi cairan, penyebukan sel radang, disertai vasodilatasi setempat yang menyebabkan udem dan pembengkakan. Tanda dan gejala klinik reaksi radang menjadi jelas berupa warna kemerahan karena kapiler melebar (rubor), suhu hangat (kalor), rasa nyeri (dolor), dan pembengkakan (tumor).

Fase ini disebut juga fase lamban karena reaksi pembentukan kolagen baru sedikit dan luka hanya dipertautkan oleh fibrin yang amat lemah.

\section{Fase Poliferasi}

Fase poliferasi disebut juga fase fibroplasia karena yang menonjol adalah proses proliferasi fibroblast. Fase ini berlangsung dari akhir fase inflamasi sampai kira-kira minggu ketiga. Fibroblast berasal dari sel mesenkim yang belum berdiferensiasi, menghasilkan mukopolisakarida, asam aminoglisin, dan prolin yang merupakan bahan dasar kolagen serat yang akan mempertautkan tepi luka.

Pada fase ini serat dibentuk dan dihancurkan kembali untuk penyesuaian diri dengan tegangan pada luka yang cenderung mengerut.Sifat ini, bersama dengan sifat kontraktil miofibroblast, menyebabkan tarikan pada tepi luka.Pada akhir fase ini kekuatan regangan luka mencapai $25 \%$ jaringan normal. Nantinya, dalam proses penyudahan kekuatan serat kolagen bertambah karena ikatan intramolekul dan antar molekul. Proses ini baru berhenti setelah epitel saling menyentuh dan menutup seluruh permukaan luka. Dengan tertutupnya permukaan luka, proses fibroplasia dengan pembentukan jaringan granulasi juga akan berhenti dan mulailah proses pematangan dalam fase penyudahan.

\section{Fase Penyudahan}

Pada fase ini terjadi proses pematangan yang terdiri dari penyerapan kembali jaringan yang berlebih, pengerutan sesuai dengan gaya gravitasi, dan akhirnya perupaan kembali jaringan yang baru terbentuk. Fase ini dapat berlangsung berbulan-bulan dan dinyatakan berakhir kalau semua tanda 
radang sudah lenyap. Tubuh berusaha menormalkan kembali semua yang menjadi abnormal karena proses penyembuhan. Udem dan sel radang diserap, sel muda menjadi matang, kapiler baru menutup dan diserap kembali, kolagen yang berlebih diserap dan sisanya mengerut sesuai dengan regangan yang ada. Selama proses ini dihasilkan jaringan parut yang pucat, tipis dan lemas serta mudah digerakkan dari dasar. Terlihat pengerutan maksimal pada luka. Pada akhir fase ini, perupaan luka kulit mampu menahan regangan kira-kira $80 \%$ kemampuan kulit normal. Hal ini tercapai kirakira $\quad 3-6 \quad$ bulan setelah penyembuhan.Perupaan luka tulang (patah tulang) memerlukan waktu satu tahun atau lebih untuk mencapai jaringan yang normal secara histologi atau secara bentuk.

Penyembuhan luka dapat terganggu oleh penyebab dari dalam tubuh sendiri (endogen) atau oleh penyebab dari luar tubuh (eksogen). Penyebab endogen terpenting adalah gangguan koagulasi dan gangguan sistem imun. Semua gangguan pembekuan darah akan menghambat penyembuhan luka sebab hemostatis merupakan titik tolak dan dasar fase inflamasi. Gangguan sistem imun akan menghambat dan mengubah reaksi tubuh terhadap luka, kematian jaringan, dan kontaminasi. Bila sistem daya tahan tubuh, baik seluler maupun humoral terganggu, maka pembersihan kontaminan dan jaringan mati serta penahanan infeksi tidak berjalan baik.Selain karena infeksi virus dan keadaan umum yang kurang baik, sistem imun dipengaruhi oleh gizi kurang akibat kelaparan, malabsorbsi, juga oleh kekurangan asam amino esensial, mineral maupun vitamin, serta oleh gangguan dalam metabolisme makanan misalnya pada penyakit hati (Sjamsuhidajat, 1997).

Berbagai faktor dapat mempengaruhi penyembuhan luka antara lain (Morison, 2002):

1. Faktor intrinsik

a. Kondisi lokal yang merugikan pada termpat luka

Kondisi lokal yang merugikan pada tempat luka dapat berupa eksudat yang berlebihan, dehidrasi, infeksi luka, trauma kambuhan, penurunan suhu luka, pasokan darah yang buruk, edema, hipoksia lokal, jaringan nekrotik dan pengelupasan jaringan yang luas, produk limbah metabolik yang berlebihan dan adanya benda asing.

b. Faktor patofisiologi umum

Faktor patofisiologi berupa terjadinnya anemia, penurunan daya tahan terhadap infeksi, gangguan metabolik dan endokrin, malnutrisi dan gangguan kardiovaskular.Faktor-faktor ini dapat mempengaruhi kondisi lokal yang merugikan pada tempat luka. 
c. Faktor fisiologis normal yang berkaitan dengan usia. Hal ini dapat mempengaruhi faktor - faktor patofisiologis umum pada pasien.

\section{Faktor ekstrinsik}

a. Penatalaksanaan luka yang tidak tepat

Penatalaksanaan luka yang tidak tepat dapat dipengaruhi oleh pengkajian luka yang tidak akurat, penggunaan agens topical dan produk balutan luka primer yang tidak sesuai, teknik penggantian balutan yang ceroboh, dan sikap negatif staf terhadap pengobatan dan penyembuhan.Faktor ini dapat mempengaruhi kondisi lokal yang merugikan pada tempat luka.

b. Efek merugikan dari terapi lain Efek merugikan dari terapi lain dapat berupa kemoterapi kanker, dosis steroid tinggi yang berkepanjangan dan terapi radiasi. Faktor ini juga dapat mempengaruhi kondisi lokal yang mempengaruhi tempat luka.

\section{PERANAN IKAN GABUS UNTUK KESEHATAN}

Dari review diatas mengenai luka maka dapat dilihat bahwa luka dapat disebabkan oleh banyak faktor, dimana peranan ikan gabus ini sudah digunakan oleh masyarakat untuk mempercepat proses penyembuhan berbagai jenis luka khususnya luka pasca operasi. Hal ini disebabkan karena ikan gabus mengandung senyawa bioaktif yang mempercepat penyembuhan luka yaitu asam-asam amino (glisin), mineral seng (Zn), dan asam-asam lemak tak jenuh seperti omega-3, omega- 6 dan omega- 9 .

Penyembuhan luka sangat mungkin membutuhkan protein, di antara zat penting lainnya, sebagai dasar untuk pembentukan jaringan kolagen. Studi menunjukkan sebuah hubungan yang signifikan antara pemberian albumin serum dan lama penyembuhan luka $(p=0,001)$. Albumin berfungsi sebagai zat pengikat dan pengangkut, pengaturan tekanan osmotik, penghambatan trombosit pembentukan dan anti-trombosis, meningkatkan permeabilitas sel, dan sebagai antioksidan (Sunatrio, 2003 dan Maryanto, 2004).

Kekurangan $\mathrm{Zn}$ dikaitkan dengan perubahan sistem kekebalan tubuh seperti penurunan fungsi sel $B$ dan $T$, reaksi hipersensitivitas, fagositosis, dan produksi sitokin. Kekurangan $\mathrm{Zn}$ juga menyebabkan gangguan penghancuran mikroba dan proses penyembuhan luka. Pemberian $\mathrm{Zn}$ per efek oral pada alkaline phosphatase meningkatkan dan mempercepat proses penyembuhan luka bedah. Ini bisa terjadi karena data menunjukkan bahwa $\mathrm{Zn}$ memegang peran penting dalam sintesis protein dan dalam multiplikasi sel. Tubuh manusia terdiri dari jaringan ikat terbuat dari protein, sehingga 
untuk membangun dan menjaga integritas jaringan ikat diperlukan Zn (Harper, et.al., 1996). Kekurangan Zn juga terkait dengan gangguan indra perasa. Anak-anak yang memiliki kandungan $\mathrm{Zn}$ rendah dapat menyebabkan di rambut mereka mengalami kelainan pada indera perasa. Ini dapat disembuhkan dengan suplementasi seng (Piliang dan Soewondo, 2006).

Disamping itu, ikan gabus sekarang sudah banyak diteliti oleh para peneliti dalam bentuk-bentuk sediaan farmasi seperti yang sudah dilakukan oleh pengarang dan sudah terpublikasi yaitu

1. Ekstrak kering ikan gabus yang dirancang dalam bentuk sediaan krim untuk mempercepat proses penyembuhan luka

2. Ekstrak kering ikan gabus yang dirancang dalam bentuk sediaan sirup double emulsi untuk meningkatkan sistem kekebalan tubuh.

3. Ekstrak kering ikan gabus yang drancang dalam bentuk sediaan nanoemulsi untuk mempercepat penyembuhan luka terbuka.

4. Ekstrak kering ikan gabus yang dirancang dalam bentuk sediaan nanoemulgel untuk mempercepat penyembuhan luka bakar.

5. Ekstrak kering ikan gabus yang dirancang dalam bentuk liposome injeksi untuk pengobatan kemoterapi kanker payudara.

Oleh karena itu, dari semua hasil-hasil penelitian yang sudah dilakukan oleh pengarang diharapkan dapat memberikan andil dalam mengembangkan sumber daya alam khususnya potensi ikan gabus sebagai senyawa bioaktif yang tidak toksik bagi tubuh.

\section{SIMPULAN}

Potensi ikan gabus dalam mempercepat proses penyembuhan luka sangat membantu meningkatkan derajat kesehatan masyarakat. Hal ini berhubungan dengan kandungan gizi yang terkandung dalam ikan gabus yaitu albumin, glisin dan $\mathrm{Zn}$. Baik albumin, glisin dan Zn penting untuk penyembuhan luka karena protein ini mampu mengikat $\mathrm{Zn}$ dan membawanya dalam plasma darah. Kekurangan $\mathrm{Zn}$ mengurangi proses penyembuhan luka. Karena nutrisi ini, dan vitamin lainnya, hadir dalam ekstrak ikan gabus sehingga dapat memicu pembentukan Sel Progenitor Endotel (EPC) dan mempercepat penyembuhan luka. Kehadiran Zn dalam ekstrak ikan gabus kemungkinan menjadi faktor kunci yang berperan dalam penyembuhan luka dan meningkatkan nafsu makan anak-anak. $\mathrm{Zn}$ adalah mineral penting dalam struktur dan fungsi membran sel. Suplementasi $\mathrm{Zn}$ dapat membatasi kerusakan membran yang disebabkan oleh radikal bebas selama peradangan. Selanjutnya, Zn juga terlibat dalam sistem kekebalan tubuh, mulai dari sistem pertahanan oleh kulit hingga regulasi gen dalam limfosit. 


\section{DAFTAR PUSTAKA}

Almatsier, S. 2001. Prinsip Dasar IImu Gizi. PT. Gramedia Pustaka Utama. Jakarta.

Asikin, A. 1999. Pengaruh Pemberian Menu Ekstra Filtrat Ikan Gabus Pada Penderita Pra Dan Pasca Operasi Di Rumah Sakit Saiful Anwar Malang. Universitas Brawijaya: Malang.

Baie, S., Sheikh, K.A. 2000. The wound healing properties of Channa striatus cetrimide cream wound contraction and glycosaminoglycan measurement. Journal Ethnopharmacol. 73:15-30.

Daldiyono, 1990. Gastroenteritis Hepatologi (Diare), hal. 21-32, CV. Sagung Seto, Jakarta.

Ghufran, M. 2010. A to Z Budidaya Biota Akuatik untuk Pangan, Kosmetik dan Obat-obatan. Penerbit ANDI: Yogyakarta

Hidayanti. 2006. Pengaruh Pemberian Kapsul Konsentrat Ikan Gabus terhadap Kadar Albumin dan Proses Penyembuhan pada Pasien Pascabedah di RS. Wahidin Sudirohusodo Makassar. Program Pascasarjana UNHAS. Makassar.

Hill, G. L. 2000. Buku Ajar Nutrisi Bedah (Disorders of Nutrition and Metabolismin Clinical Surgery Under Standing and Management). Alih Bahasa : Darman Lyan. Jakarta.

Harper, H,A., Mayes, P.A., Rodwell V.W. 1996. Biochemistry, ed. 17th, Translator: Muliawan, EGC, Jakarta. (in Indonesian).

Jahoor, Farook. 1999. Chronic Protein Undernutrition and An Acute Inflammatory Stimulus Elicit Different Protein Kinetic Responses in Plasma but Not in Muscle of Piglets. Journal of Nutrition. 129: 693-699.
Lawang, T.A. 2013. Pembuatan Dispersi Konsentrat Ikan Gabus (Ophiocephalus Striatus) Sebagai Makanan Tambahan (Food Supplement). Skripsi. UNHAS: Makassar

Maryanto, A. 2004. The Impact of Albumin Serum on Length of Postoperative Wound Healing Process, Faculty of Medicine, University of Gadjah Mada, Abstract. (in Indonesian)

Mustafa, A., Widodo, A., Kristianto, Y. 2012. Albumin and zinc content of snakehead fish extract and its role in health. Int. J. Sci Techno. 1(2):1-8.

Piliang, W.G., Soewondo, D. 2006. Nutrition Physiology. Vol 2. IPB Press, Bogor. (in Indonesian).

Sulthoniyah, S.T.M. 2013. Pengaruh Suhu Pengukusan Terhadap Kandungan Gizi Dan Organoleptik Abon Ikan Gabus (Ophiocephalus Striatus). THPi Student Journal. 1(1):33-45.

Sunatrio, S. 2003. Peran albumin pada Penyakit Kritis, dalam Konsensus Pemberian Albumin pada Sirosis Hati. FKUI Press: Jakarta.

Suprapti, L. 2008. Teknologi Pengolahan Pangan: Produk Olahan lkan. Penerbit KANISIUS: Yogyakarta.

Suprayitno, E. 2003. Albumin Ikan Gabus (Ophiocephalus striatus) sebagai Makanan Fungsional Mengatasi Permasalahan Gizi Masa Depan. Fakultas Perikanan Universitas Brawijaya: Malang.

Sunatrio, S. 2003. The Role of Albumin on Chronic Disease, in Consensus of Albumin Administration for Cirrhosis Hepatic. Faculty of Medicine University of Indonesia. Jakarta. (in Indonesian). 
Simanjuntak, J.P. 1994. .Manajemen Keselamatan Kerja. Jakarta: HIPSMI.

Supariasa, D.I.N. 2002. Penilaian Status Gizi. Jakarta. Penerbit Buku Kedokteran EGC.

Taslim, A.N., Hadju, V., Attamimi, F., Tawali, A.A., Saifuddin. 2005. Laporan Penelitian Ikan Gabus. Pusat Penelitian Pangan, Gizi dan Kesehatan UNHAS. Makassar.

Tungadi, R., Attamimi, F. 2011. Percepatan Penyembuhan Luka oleh Krim Ikan Gabus (Ophiocephalus striatus) Terhadap Luka Kulit Kelinci (Oryctolagus cuniculus) Secara Histopatologi. Jurnal IImu Kefarmasian Indonesia. 9(2): 91-97.

Tungadi, R., Susanty, W., Wicita, P., Pido, E. 2018. Transdermal delivery of snakehead fish (Ophiocephalus striatus) nanoemulgel containing hydrophobic powder for burn wound. Pharm Sci 24(4):313-23.

Tungadi, R., Hasan, A.M. 2016. The effect of penetrant enhancer combination towards the diffusion rate of snakehead fish (Ophiocephalus striatus) cream in vitro and vivo. Int J Pharmtech Res. 9(6): 50813.

Tungadi, R., Moo, D.R., Mozin W.R. 2017. Characterization and Physical Stability Evaluation of Snakehead Fish (Ophiocephalus Striatus) Powder Nanoemulsion. Int J Pharm Sci Res. 8(6):2720-4.

Tungadi, R., Imran, A.K. 2018. Formulation development and characterization of snakehead fish powder in oral double emulsion. Int J App Pharm. 10(2):70-5.

Tawali, A. B. 2012. Difusi Teknologi Produksi Konsentrat Protein Dari Ikan Gabus Sebagai Food Supplement Di Jayapura. UNHAS: Makassar.
Ulandari, A. 2011. Potensi Protein Ikan Gabus Dalam Mencegah Kwashiorkor Pada Balita Di Provinsi Jambi. Fakultas Kedokteran Universitas Jambi: Jambi.

Winarno, 1993. Food, Nutrition, Technology and The Consumer. Gramedia Pustaka Utama. Jakarta. 